\title{
New records of lichens and allied fungi from the Kostroma Region, Russia
}

\author{
Irina Urbanavichene ${ }^{1} \&$ Gennadii Urbanavichus ${ }^{2}$ \\ ${ }^{1}$ Komarov Botanical Institute RAS, Professor Popov Str. 2, 197376 St Petersburg, Russia. \\ E-mail: urbanavichene@gmail.com \\ ${ }^{2}$ Institute of North Industrial Ecology Problems, Kola Science Centre RAS, Akademgorodok 14a, 184209 Apatity, \\ Murmansk Region, Russia. E-mail: g.urban@mail.ru
}

\begin{abstract}
: 29 species of lichens, 3 non-lichenized calicioid fungi and 3 lichenicolous fungi are reported for the first time from the Kostroma Region. Among them, 15 species are new for the Central Federal District, including Myrionora albidula - a rare species with widely scattered locations, previously known only from the Southern Urals Mts in European Russia. The most important discoveries are confined to old-growth coniferous Picea sp. and Abies sibirica forests in the Kologriv Forest Nature Reserve. Two species (Leptogium burnetiae and Menegazzia terebrata) are included in the Red Data Book of Russian Federation. The distribution, ecology, taxonomic characters and conservation status of rare species and of those new for the Central Federal District are provided.
\end{abstract}

Keywords: Biatora mendax, Myrionora albidula, old-growth forests, southern taiga, Kologriv Forest Reserve, Central European Russia

\section{INTRODUCTION}

The Kostroma Region is a large $\left(60,211 \mathrm{~km}^{2}\right)$, most northeastern part of the Central Federal District in European Russia situated between Ivanovo, Yaroslavl, Vologda, Kirov and Nizhniy Novgorod regions (Fig. 1). It is located within the Eastern European Plain, once covered with ice during the Moscow glaciation which determined its modern topography. The regional relief is mostly flat with swampy lowlands and occasional moraines within the Volga River Basin. The climate is temperate-continental, with cold winters and warm summers; the average temperature is $-13{ }^{\circ} \mathrm{C}$ in January and $+18{ }^{\circ} \mathrm{C}$ in July; the annual average precipitation in the region is between $650 \mathrm{~mm}$ in the $\mathrm{W}$ and 550 $\mathrm{mm}$ in the NE (Red Data Book of Kostroma Region, 2009). Most of the Kostroma Region is located within the southern taiga subzones, where the natural forest landscapes have been heavily transformed by long-term human activity. Today the forests occupy c. $74 \%$ of the area of the region, of which about two-thirds are dominated by young or middle-aged tree stands (Dudin, 2000).

Early lichenological investigations of the Kostroma Region relate to the work of Elenkin (1906, 1907, 1911) and Ladyzhenskaya (1931), who published first data for Kostromskaya Gu- berniya, listing 39 and 54 taxa, respectively. The recent published additions to the Kostroma lichen flora are from the Kologriv District by

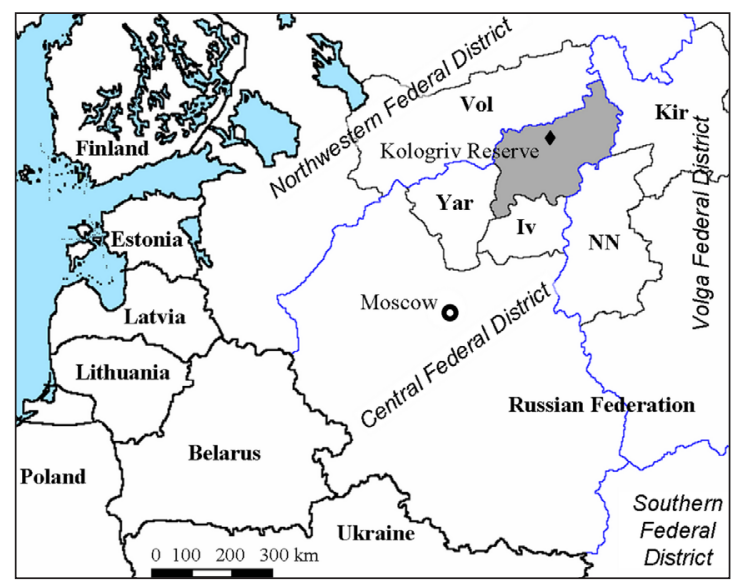

Fig. 1. The location of the Kologriv Forest Reserve (diamond) and Kostroma Region (grey color) in the northeastern part of the Central Federal District. The abbreviations of the neighbouring regions: Iv - Ivanovo, Yar - Yaroslavl (within Central Federal District), Vol - Vologda (Northwestern Federal District), Kir - Kirov and NN - Nizhniy Novgorod (Volga Federal District). Blue line - the borders of the Federal Districts. 
Kuznetsova and Skazina (2010) and the Makaryev and Chukhloma Districts by Himelbrant et al. (2018). In all, 190 species have been reported from the Kostroma Region.

Our results are based on investigations from field trips made in September 2018 to the Kologriv Forest State Nature Reserve (c. 59,000 hectares in size), established in 2006 in the northern part of the Kostroma Region $\left(58^{\circ} 55^{\prime} \mathrm{N}\right.$, $43^{\circ} 52^{\prime} \mathrm{E}$ ) in order to preserve southern taiga nature landscapes of the Russian plain. The territory of the reserve is dominated by a wavy relief generated by hills and inter-fluvial ranges from 150 to $180 \mathrm{~m}$ a.s.1. Rocky outcrops are absent, but erratic granitic, sometimes rather large, boulders are scattered throughout the territory. Forest management and clear-cutting was applied within this territory in 1950-1990s, the current landscape mostly represents recovering secondary deciduous and mixed deciduousconiferous forests. Our field studies were carried out in the best-conserved old-growth fir-spruce and mixed aspen-spruce or lime-spruce forest communities.

The first investigation of the Kologriv Forest Reserve by lichenologists was carried out in the summer 2008 (Kuznetsova \& Skazina, 2010) when 95 species of lichens and allied fungi were recorded. The present paper provides additions to the lichen flora of both the Kostroma Region and Kologriv Forest Reserve.

\section{MATERIAL AND METHODS}

Lichen specimens were collected from five localities in the northern part of the Kologriv Forest Reserve (Kologriv District, Kostroma Region).

1 - Quarter no. 24, right bank of the Sekha River, old-growth spruce-fir forest of Picea sp. and Abies sibirica Ledeb., with Betula sp., Populus tremula L., Tilia cordata L., Salix sp. and Alnus incana (L.) Moench.; 58 $55^{\prime} 31.3^{\prime \prime N}$, 4349'44.2”E, alt. c. $150 \mathrm{~m}, 02.09 .2018$.

2 - Quarter no. 22, old-growth mixed forest of Picea sp., Tilia cordata, Betula sp., Populus tremula, with Sorbus aucuparia L., young Acer platanoides L. and Fraxinus excelsior L.; $58^{\circ} 55^{\prime} 15.4^{\prime \prime} \mathrm{N}, 43^{\circ} 46^{\prime} 24.1$ 'E, alt. c. $180 \mathrm{~m}$, 03.09.2018. (Fig. 2).

3 - Quarter no. 31, old-growth mixed forest of Populus tremula and Picea sp. with Pinus syl-

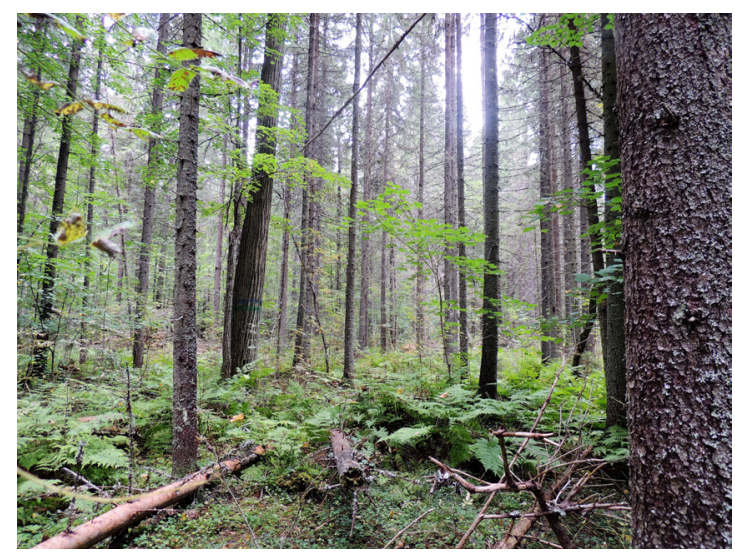

Fig. 2. The old-growth mixed forest of Picea sp., Tilia cordata, Betula sp. and Populus tremula in locality no. 2.

vestris L.; $58^{\circ} 53^{\prime} 39.2^{\prime \prime} \mathrm{N}, 43^{\circ} 51^{\prime} 25^{\prime \prime} \mathrm{E}$, alt. c. 165 $\mathrm{m}, 05.09 .2018$.

4 - Quarter no. 17, right bank of the Sekha River, old-growth mixed forest of Picea sp., Abies sibirica and Tilia cordata; 58 $56^{\prime} 34.2^{\prime \prime} \mathrm{N}$, 4350'42"E, alt. c. $145 \mathrm{~m}, 06.09 .2018$.

5 - Quarter no. 17, right bank of the Sekha River, old-growth spruce-fir forest of Picea sp., Abies sibirica with Betula sp.; 58 $56^{\prime} 06,7^{\prime \prime} \mathrm{N}$, $43^{\circ} 50$ '14,8”E, alt. c. $145 \mathrm{~m}, 06.09 .2018$.

Air-dried specimens were examined using a stereo microscope, a light microscope and the usual spot tests with standard identification methods for lichenized and lichenicolous fungi; high performance thin-layer chromatography was undertaken where necessary (Orange et al., 2001). All listed specimens are deposited in the herbarium of Komarov Botanical Institute (LE) and in the personal herbarium of G. Urbanavichus. The nomenclature of the cited taxa mainly follows Nordin et al. (2011). The listed species are accompanied by the data on substrates, localities, distributions and references, and the most interesting records are briefly discussed. WGS 84 system was used for geographical (GPS) coordinates. In the following list of species, lichenicolous fungi are indicated by \# and non-lichenized fungus by + , and the following abbreviations are used: CFD - Central Federal District, NWFD - Northwestern Federal District, VFD - Volga Federal District. 


\section{THE SPECIES}

ARthonia RUANA A. Massal. - 2: on smooth bark of Fraxinus excelsior. Distribution in neighbouring territories: Yaroslavl Region (Muchnik et al., 2007) and Nizhniy Novgorod Region (Urbanavichene \& Urbanavichus, 2001). In Russia occurs sporadically from the north of the European part to the southern part of the Far East. It is a widely distributed species in the Northern Hemisphere.

Biatora MEIOCARPA (Nyl.) Arnold - 2: on decaying wood of stump of Picea sp.; 3: on bark of Pinus sylvestris. Unreported from neighbouring territories. In CFD previously known from Tver Region (Notov et al., 2011). The nearest locality in European Russia is known in VFD from Republic of Mari El (Bogdanov, 2015). Differs from the related species $B$. helvola Körb. ex Hellb. by ellipsoid or rectangular lumina of excipular hyphae, c. $7 \times 3.5 \mu \mathrm{m}$, enlarged paraphyses-ends, c. 3.6-5.2 $\mu \mathrm{m}$ wide and presence of filiform conidia, c. $30 \times 1.5 \mu \mathrm{m}$ (Ekman, 1994). Apothecia and thallus of $B$. helvola contain gyrophoric acid and $\mathrm{C}+$ rose-red (Printzen \& Otte, 2005). It is a widely distributed species in the Northern Hemisphere.

Biatora mendaX Anzi - 1: on bark of Abies sibirica. Unreported from neighbouring territories. New to CFD. In Russia recently published from the Northern Caucasus (Urbanavichene \& Urbanavichus, 2014). Characterized by an esorediate PD+ red thallus, 1-celled ascospores, 2.5-5 $\mu \mathrm{m}$ wide, dark apothecia, and a brown epihymenium (sometimes also the hymenium and subhymenium) that is N- (Printzen \& Otte, 2005). B. mendax is a very rare species and confined to old-growth coniferous or mixed forest; in Europe, it follows more or less the distribution area of Abies alba Mill. (Printzen \& Palice, 1999). In the world it is known from the Central and Southern Europe (Austria, Czech Republic, France, Germany, Italy, Montenegro, Poland, Slovakia, Slovenia, Spain, Switzerland), the Caucasian region (Russia) and North America (U.S.A.).

Bryobilimbia sanguineoatra (Wulfen) Fryday, Printzen \& S. Ekman - 1: on mossy fallen trunk of Picea sp. Unreported from neighbouring territories. The distribution of this species in Russia requires further investigation since it was previously treated as a synonym of Mycobilimbia hypnorum (Lib.) Kalb \& Hafellner. B. sanguineoatra has been recently reported from the Baikal Siberia (Urbanavichene et al., 2018), Republic of Mordovia (Urbanavichene \& Urbanavichus, 2015) and Republic of Adygea (Otte, 2001, as Mycobilimbia sanguineoatra (Wulfen) Kalb \& Hafellner). The species Lecidea sanguineoatra auct., previously reported from some localities in Russia, e.g. Leningrad and Moscow Regions (Tomin, 1956), Magadan Region (Korolev \& Tolpysheva, 1980) and Altai Territory (Davydov \& Printzen, 2012), may also belong to $B$. sanguineoatra. Distinguished from $B$. hypnorum by mainly simple, narrowly ellipsoid ascospores, $<5$ $\mu \mathrm{m}$ wide, with a smooth and unwarted perispore (Fryday et al., 2014).

Bryoria Kuemmerleana (Gyeln.) Brodo \& D. Hawksw. - 5: on bark of Picea sp. Distribution in neighbouring territories: Nizhniy Novgorod Region (Sharapova, 2001). New to CFD. Thallus to $15 \mathrm{~cm}$, hanging, ash-grey or brownishgrey, with fairly thick branches $0.5-0.8 \mathrm{~mm}$ in diam., with $\mathrm{KOH}+$ red and $\mathrm{PD}+$ yellow to orange reactions. TLC: norstictic acid, connorstitic and atranorin. Rather common but not so frequently reported species; in Europe it is widespread from Fennoscandia to Mediterranean region, and recorded also in Southwestern Asia from Caucasian region (Russia, Iran) (Velmala et al., 2014; Urbanavichene, 2018).

Chaenotheca Chlorella (Ach.) Müll. Arg. - 1: on bark of Tilia cordata and lignum of Abies sibirica stump; 5: on lignum of Betula sp. stump. Unreported from neighbouring territories. In CFD previously known from Tver Region (Notov et al., 2011). The nearest localities in European Russia are known in VFD from Republic of Mari El (Bogdanov, 2015) and Republic of Mordovia (Urbanavichene \& Urbanavichus, 2015). Specialized species of biologically valuable old-growth forests in North-Western European Russia (Andersson et al., 2009).

Chaenotheca GRacillima (Vain.) Tibell - 4: on lignum of Abies sibirica stump. Unreported from neighbouring territories. In CFD previously known from Tver Region (Notov et al., 2011). The nearest locality in European Russia is known in VFD from Republic of Mari El (Bogdanov, 2015). Specialized species of biologically valuable oldgrowth forests in North-Western European Russia (Andersson et al., 2009).

Chaenotheca subroscida (Eitner) Zahlbr. - 2: on lignum of Picea sp. stump. Unreported from neighbouring territories. In CFD previously 
known from Tver Region (Notov et al., 2011). Specialized species of biologically valuable old-growth forests in North-Western European Russia (Andersson et al., 2009). It is widely distributed in cool temperate and temperate areas of western Eurasia and western North America (Tibell \& Beck, 2001). In Russia it occurs sporadically from the north of European part to Western Siberia.

+Chaenothecopsis pusiola (Ach.) Vain. - 4: on lignum of Abies sibirica stump; 5: on lignum of Picea sp. stump. Distribution in neighbouring territories: Yaroslavl Region (Muchnik et al., 2007). The nearest locality in European Russia is known in VFD from Republic of Mari E1 (Bogdanov, 2015). An indicator species of biologically valuable old-growth forests in North-Western European Russia (Andersson et al., 2009).

+Chaenothecopsis viridireagens (Nádv.) A. F. W. Schmidt - 2: on bark of Picea sp. Distribution in neighbouring territories: Yaroslavl Region (Muchnik et al., 2007). The nearest locality in European Russia is known in VFD from Republic of Mordovia (Urbanavichus \& Urbanavichene, 2014). Specialized species of biologically valuable old-growth forests in North-Western European Russia (Andersson et al., 2009).

Cheiromycina PETRI D. Hawksw. \& Poelt - 1: on bark of Abies sibirica. Unreported from neighbouring territories. New to CFD. Lichenized hyphomycete with bluish-grey hemisphaerical sporodochia, palmate branched multicellular conidia, slightly enlarged conidiogenous cells and terminal branches of conidia with 1-2 cells (Printzen, 2007). In European Russia previously known only in NWFD from Leningrad Region (Himelbrant et al., 2013). Specialized species of biologically valuable old-growth forests in North-Western European Russia (Andersson et al., 2009). It is widespread in Holarctic region, with a few records in Russia from Leningrad Region, Caucasus and Far East.

CREsponea Chloroconia (Tuck.) Egea \& Torrente - 2: on bark of Picea sp. and Tilia cordata; 5: on bark of Picea sp. Unreported from neighbouring territories. In CFD known from Tver Region (Notov et al., 2011), Moscow Region (Kopaczevskaja et al., 1977). The nearest locality in European Russia is known in VFD from Republic of Mari El (Bogdanov, 2015).
\#DACTYlospora lobariella (Nyl.) Hafellner - 3: on thallus of Lobaria pulmonaria (L.) Hoffm. growing on Populus tremula. Unreported from neighbouring territories. New to CFD. The nearest locality in European Russia is known in NWFD from Komi Republic on the Northern Ural (Zhurbenko, 2004). This is a subcosmopolitan species reported on many species of Lobaria and Ricasolia. In addition to Komi Republic, it was formerly known in Russia from the Caucasus, Krasnoyarsk Territory, Republic of Altai and Primorye Territory (Zhurbenko, 2017).

Dictyocatenulata alba Finley \& E. F. Morris - 1: on decaying wood of stump of Picea sp. Unreported from neighbouring territories. New to CFD. The nearest locality in European Russia is known in NWFD from Leningrad Region (Stepanchikova et al., 2010). It is rather widespread in tropical, subtropical, broad-leaved zones and is known from Northern and Central America, Asia, and Central and Eastern Europe. In Russia previously known also from the Far East, and more recently from the Baikal Siberia (Urbanavichene et al., 2018).

EVernia Divaricata (L.) Ach. - 1: on bark of Picea sp. Distribution in neighbouring territories: Vologda Region (Czhobadze \& Philippov, 2014) and Nizhniy Novgorod Region (Urbanavichene \& Urbanavichus, 2001). Specialized species of old-growth forests in North-Western European Russia (Andersson et al., 2009).

\#HETERocephalacria PHYSCIACEARUM (Diederich) Millanes \& Wedin - 3: on thallus of Physcia aipolia (Ehrh. ex Humb.) Fürnr. growing on bark of Populus tremula. Unreported from neighbouring territories. New to CFD. The nearest locality in European Russia is known in VFD from Republic of Mordovia (Urbanavichus \& Urbanavichene, 2014). This is a common lichenicolous heterobasidiomycete with subcosmopolitan distribution that grows on members of Physciaceae.

HyPogymia InCURVOIDES Rass. - 1: on bark of Abies sibirica; 4: on bark of Betula sp. Unreported from neighbouring territories. New to CFD. The nearest localities in European Russia are known in NWFD from Archangelsk Region (Rassadina, 1967) and in VFD from Republic of Mordovia (Urbanavichus \& Urbanavichene, 2015). Elsewhere in the world it is known from Northern Europe (Sweden and Norway), the coast of eastern North America (Canada and 
U.S.A.), Greenland (Hansen \& McCune, 2010), and northeastern China (Divakar et al., 2019). $H$. incurvoides is most similar to $H$. physodes (L.) Nyl., but is readily distinguished from that species by the presence of holes in the lobe tips and axils, black-margined lobes forming a regular lattice, and the absence of 3-hydroxyphysodic acid. This substance gives a $\mathrm{K}+$ reddish-brown reaction in the medulla, which is consistently seen in $H$. physodes but not in $H$. incurvoides (McCune et al., 2007).

LECANIA CROATICA (Zahlbr.) Kotlov - 1: on bark of Prunus padus L.; 4: on bark of young Picea sp. Unreported from neighbouring territories. New to CFD. The nearest locality in European Russia is known in VFD from Republic of Mordovia (Urbanavichene \& Urbanavichus, 2015). It is an inconspicuous, easily overlooked, corticolous lichen with a sorediate thallus lacking lichen metabolites, with small pale apothecia and $0-1$-septate ascospores. It is morphologically very similar to Mycobilimbia epixanthoides (Nyl.) Vitik. et al. ex Hafellner \& Türk: both taxa are sorediate, lack lichen substances, and produce pale biatorine apothecia. In the sterile state they may be separated on the basis of substrate preference: $L$. croatica grows exclusively on the bark of trees while $M$. epixanthoides prefers bryophytes and is rarely corticolous (Hafellner et al., 2005; Harris \& Lendemer, 2010; Kukwa et al., 2012).

LECANORA THYSANOPHORA R.C. Harris - 2: on bark of Tilia cordata. Unreported from neighbouring territories. In CFD previously known from Tver Region (Notov et al., 2011), Bryansk Region (Muchnik et al., 2017), Oryol Region (Muchnik, 2013a) and Voronezh Region (Muchnik, 2013b). This sorediate species is distinctive mainly by its arachnoid prothallus and chemistry. In the field it may resemble Haematomma ochroleucum (Neck.) J. R. Laundon, Lecanora expallens Ach. or Loxospora elatina (Ach.) A. Massal. Lecanora thysanophora can be easily separated by TLC as it produces atranorin, usnic acid, zeorin and specific terpenoids called "thysanophoraunknowns" (Harris et al., 2000; Kukwa, 2005).

LEPRA MUlTipuncta (Turner) Hafellner (= Pertusaria multipuncta (Turner) Nyl.) - 2: on bark of Fraxinus excelsior. Unreported from neighbouring territories. New to CFD. The species is known in European Russia only from the Kaliningrad region (Dedkov et al., 2007). L. multipuncta can be mistaken for the morphologically similar $L$. ophthalmiza (Nyl.) Hafellner. Both species produce similar soralium-like apothecia, but they can be easily separated by spot test reaction PD and thin layer chromatography: L. multipuncta reacts $\mathrm{PD}+$ orange-red, $\mathrm{KOH}+$ yellow and contains physodalic acid, often together with protocetraric acid, and L. ophthalmiza is PD- and has fatty acids (Oset \& Kukwa, 2010).

LePTOGium BURNetiae C. W. Dodge - 1: on bark of Populus tremula. Unreported from neighbouring territories. In CFD previously known from Tver Region (Notov et al., 2011). L. burnetiae may in certain forms be difficult to separate from $L$. saturninum (Dicks.) Nyl. It is, however, a thinner, bluer species with more coralloid isidia, that often forming patchy clusters on the surface (Jørgensen \& Nash, 2004). A red-listed species in the Russian Federation (Red Data Book of Russian Federation, 2008).

LePTOGium Cyanescens (Rabenh.) Körb. - 1: on mossy fallen decaying tree of Populus tremula. Distribution in neighbouring territories: Kirov Region (Andreev, 1999), Nizhniy Novgorod Region (Urbanavichene \& Urbanavichus, 2001). In CFD previously known from Tver Region (Notov et al., 2011), Ryazan Region (Zhdanov \& Volosnova, 2008). L. cyanescens is an indicator species of biologically important old-growth forests in the southern taiga of North-Western European Russia (Andersson et al., 2009).

Loxospora Cismonica (Beltr.) Hafellner -1 and 5: on bark of Abies sibirica. Distribution in neighbouring territories: Nizhniy Novgorod Region (Presnyakova, 2001). New to CFD. In VFD known from Republic of Mari El (Bogdanov, 2015). This is the third record for Russia. Known only from Central Europe and North America, but absent from Northern Europe, this very rare species is only found in extremely humid, cool and undisturbed forest stands. It is mostly found on old Abies in spruce-fir and fir-beech forests (Printzen et al., 2002). Within the area (Kostroma and Nizhniy Novgorod Regions, Republic of Mari $\mathrm{El}$ ), the species is confined to old-growth sprucefir forests in the protected nature territories - Kologriv and Bolshaya Kokshaga Reserves, sanctuary "Klenovik" and nature park "The spruce-fir forests on Shade and Agrafenka Rivers" (Presnyakova, 2001; Bogdanov, 2015). Due 
to its special habitat requirements, it is classified here as an indicator of old-growth spruce-fir forests in the southern taiga of European Russia.

Menegazzia terebrata (Hoffm.) A. Massal. - 2: on bark of Tilia cordata. Distribution in neighbouring territories: Nizhniy Novgorod Region (Sharapova, 2001; Urbanavichene \& Urbanavichus, 2001). In CFD, currently known from Tver Region (Notov et al., 2011) and Smolensk Region (Muchnik et al., 2018a). Specialized species of biologically valuable old-growth forests in North-Western European Russia (Andersson et al., 2009). A red-listed species in the Russian Federation (Red Data Book of Russian Federation, 2008).

Micarea hedlundi Coppins - 2: on bark of Picea sp.; 3: on lignum of Pinus silvestris stump. Unreported from neighbouring territories. In CFD previously known from Tver Region (Notov et al., 2011). The nearest locality in European Russia is known in VFD from Republic of Mordovia (Urbanavichus \& Urbanavichene, 2015). This species has been described from Norway and is currently known from several localities in Europe (e.g., Austria, Germany, Lithuania, Norway, Poland, Sweden, Ukraine, etc.). It has also been reported from Africa (Rwanda), North America (Canada, USA) and South America (Chile) (Czarnota, 2007).

Myrionora alBidula (Willey) R. C. Harris - 1: on bark of Salix sp. Distribution in neighbouring territories: not reported. New to CFD. Formerly known in European Russia only from the Southern Ural Mts. (Urbanavichene et al., 2013). In Russia known from the Southern Siberia and Far East (Palice et al., 2013). Elsewhere in the world it is known from North and Central Europe (Sweden, Norway, Germany), and the eastern and western coasts of North America (U.S.A.) (Palice et al., 2013). M. albidula is rare, but widespread throughout the northern temperate zone. It has been widely overlooked but may turn out to be locally frequent; it forms very small thalli with minute apothecia, which, even if detected, may be mistaken for juvenile or stunted apothecia of other crustose lichens with biatorine apothecia (Palice et al., 2013).

Peltigera NEOPOlydactyla (Gyeln.) Gyeln. - 1: on mossy trunk base of Populus tremula; 2: on mossy trunk base of Salix sp. Distribution in neighbouring territories: Yaroslavl Region (Muchnik et al., 2018b) and Nizhniy Novgorod Region (Presnyakova, 2001).

\#Plectocarpon lichenum (Sommerf.) D. Hawksw. -3 : on thallus of Lobaria pulmonaria growing on Populus tremula. Unreported from neighbouring territories. In CFD previously known only from Tver Region (Notov \& Himelbrant, 2013).

Ramalina thrausta (Ach.) Nyl. - 1: on branches of Picea sp.; 5: on branches and bark of Abies sibirica. Distribution in neighbouring territories: Yaroslavl Region (Muchnik et al., 2007), Vologda Region (Czhobadze \& Philippov, 2015) and Nizhniy Novgorod Region (Urbanavichene \& Urbanavichus, 2001). $R$. thrausta is exclusively confined to old-growth undisturbed wet spruce forests in North-Western European Russia (Andersson et al., 2009).

RinOdina SUBPARIATA (Nyl.) Zahlbr. (= Rinodina degeliana Coppins) - 1: on bark of Alnus incana. Unreported from neighbouring territories. In CFD previously known from Tver Region (Notov et al., 2014). The nearest localities in European Russia are known in VFD from Republic of Mari El (Bogdanov, 2015) and Republic of Mordovia (Urbanavichene \& Urbanavichus, 2015). It is widespread in Europe from Fennoscandia to Mediterranean and from British Islands to Carpathian Mts., in Asia and North America (Czarnota et al., 2018).

Rostania occultata (Bagl.) Otálora, P. M. Jørg. \& Wedin - 2: on bark of old Salix sp. Unreported from neighbouring territories. New to CFD. The nearest locality in European Russia is known in NWFD from Novgorod Region (Tagirdzhanova et al., 2014). Specialized species of biologically valuable old-growth forests in the southern taiga of North-Western European Russia (Andersson et al., 2009).

Sclerophora CONIOPHAEA (Norman) Mattsson \& Middelb. - 1: on bark of old Picea sp. Unreported from neighbouring territories. In CFD previously known from Tver Region (Notov et al., 2011). The nearest localities in European Russia are known in VFD from Republic of Mari El (Bogdanov, 2015) and Republic of Mordovia (Urbanavichene \& Urbanavichus, 2015). Specialized species of biologically valuable old-growth forests in North-Western European Russia (Andersson et al., 2009). 
+STENOCYBe MAJOR Nyl. ex Körb. - 1: on bark of Abies sibirica. Unreported from neighbouring territories. New to CFD. The nearest locality in European Russia is known in NWFD from southern part of Komi Republic (Pystina, 2003).

TRAPELIA CORTICOLA Coppins \& P. James - 5: on decaying wood of Picea sp. Unreported from neighbouring territories. New to CFD. The nearest locality in European Russia is known in NWFD from Leningrad Region (Himelbrant et al., 2018). This usually sterile, sorediate species is characterized by its effuse, \pm immersed, green to greenish brown thallus consisting of scattered areoles; soralia are greenish, usually punctiform and markedly convex (Czarnota \& Kukwa, 2009). TLC: gyrophoric (major) and lecanoric acids, a trace of 5-O-methylhiascic acid.

TuCKermannopsis CILIARIS (Ach.) Gyeln. - 1: on bark of Betula sp. Distribution in neighbouring territories: Vologda Region (Czhobadze \& Philippov, 2015). New to CFD. Kologriv Forest Reserve is the southernmost locality of this species in European Russia.

\section{DISCUSSION}

The above list contains 29 species of lichenforming, 3 non-lichenized calicioid and 3 lichenicolous fungi (altogether 35 species) which are new to the Kostroma region and Kologriv Forest Reserve. Most species are rarely reported or unreported from the neighbouring regions. They are probably overlooked owing to their small size and inconspicuous thalli. 15 species are recorded for the first time for the Central Federal District: Biatora mendax, Bryoria kuemmerleana, Cheiromycina petri, Dactylospora lobariella, Dictyocatenulata alba, Heterocephalacria physciacearum, Hypogymnia incurvoides, Lecania croatica, Lepra multipuncta, Loxospora cismonica, Myrionora albidula, Rostania occultata, Stenocybe major, Trapelia corticola and Tuckermannopsis ciliaris, of which Biatora mendax is new to European Russia. Myrionora albidula is a rare species with scattered distribution, previously recorded only once in European Russia from the Southern Urals Mts. The most important discoveries are confined to old-growth coniferous Picea sp. and Abies sibirica forests in the Kologriv Forest Nature Reserve.
The territory of the Reserve has been significantly disturbed by intensive logging and clearcutting, but still includes a few remnants of small native forest sites (less $10 \%$ of the total area of the Reserve). Therefore, we can not expect to find here a large number of indicator or specialized species of biologically valuable and old-growth forests of southern taiga. However, the importance of even small remaining sites of old-growth forests for the maintenance of biodiversity is clearly illustrated by the results of this field-study. Of the 35 listed species, 14 are indicators (Chaenothecopsis pusiola, Leptogium cyanescens, Loxospora cismonica) or habitat specialists (Biatora mendax, Chaenotheca chlorella, C. gracillima, C. subroscida, Chaenothecopsis viridireagens, Cheiromycina petri, Evernia divaricata, Menegazzia terebrata, Ramalina thrausta, Rostania occultata, Sclerophora coniophaea) of biologically valuable and old-growth forests in southern taiga of European Russia (Andersson et al., 2009). Ten of them were collected from bark or wood of Abies sibirica and Picea sp. Two species, Leptogium burnetiae and Menegazzia terebrata, are red-listed and protected in the Russian Federation (Red Data Book of Russian Federation, 2008). In consequence of this work, the lichen flora of the Kologriv Nature Reserve comprises 130 species and the Kostroma Region 225 species (Elenkin, 1906, 1907, 1911; Ladyzhenskaya, 1931; Kuznetsova \& Skazina, 2010; Himelbrant et al., 2018). It is also evident that the lichen flora of old-growth spruce and mixed forests of Kostroma Region is in need of more intensive studies.

\section{ACKNOWLEDGEMENTS}

We are grateful to Sergei Chistyakov for organizing the expedition to the Kologriv Forest Reserve. We express our gratitude to Prof. Mark Seaward who kindly corrected the English. We are grateful to anonymous reviewer and Tiina Randlane for valuable corrections and comments. The work of Irina Urbanavichene was carried out within the framework of the research program of the Komarov Botanical Institute of the Russian Academy of Sciences (no. AAAAA19-119020690077-4). 


\section{REFERENCES}

Andersson, L., Alexeeva, N. \& Kuznetsova, E. (eds). 2009. Survey of biologically valuable forests in North-Western European Russia. Vol. 2. Identification manual of species to be used during survey at stand level. St. Petersburg. 258 pp. (In Russian).

Andreev, M. P. 1999. Materials to the study of lichen flora Kirov Region (lichens of Reserve "Nurgush"). Novitates Systematicae Plantarum Non Vascularium 33: 98-107. (In Russian).

Bogdanov, G. A. 2015. A list of lichens for the "Bolshaya Kokshaga" Nature Reserve. Scientific Papers of the State Nature Reserve "Bolshaya Kokshaga". Issue. 7. Yoshkar-Ola, Volga State University of Technology. Pp. 206-244. (In Russian).

Czarnota, P. 2007. The lichen genus Micarea (Lecanorales, Ascomycota) in Poland. Polish Botanical Studies 23: 1-199.

Czarnota, P. \& Kukwa, M. 2009. Contribution to the knowledge of some poorly known lichens in Poland. III. Trapelia corticola and the genus Vezdaea. Folia Cryptogamica Estonica 46: 25-31.

Czarnota, P., Mayrhofer, H. \& Bobiec, A. 2018. Noteworthy lichenized and lichenicolous fungi of open-canopy oak stands in east-central Europe. Herzogia 31: 172-189. https://doi. org/10.13158/099.031.0111

Czhobadze, A. B. \& Philippov, D. A. 2015. New location of protected species of lichens in the Vologda Region. Phytodiversity of Eastern Europe 9(1): 121-131.

Davydov, E. A. \& Printzen, C. 2012. Rare and noteworthy boreal lichens from the Altai Mountains (South Siberia, Russia). Bryologist 115: 61-73. https://doi.org/10.1639/0007-2745.115.1.61

Dedkov, V. P, Andreev, M. P. \& Petrenko, D. E. 2007. Annotated list of lichens of the Kaliningrad Region. In: Biodiversity of the Kaliningrad Region 1. Kaliningrad. Pp. 79-178. (In Russian).

Diederich, P., Palice, Z. \& Ertz D. 2008. Cheiromycina ananas is a synonym of Dictyocatenulata alba, a widespread, lichenized, synnematous hyphomycete herewith reported as new for Europe. Sauteria 15: 205-214.

Divakar, P. K., Wei, X.-L., McCune, B., Cubas, P., Boluda, C. G., Leavitt, S. D., Crespo, A., Tchabanenko, S. \& Lumbsch, H. T. 2019. Parallel Miocene dispersal events explain the cosmopolitan distribution of the Hypogymnioid lichens. Journal of Biogeography 46: 945-955. https: / doi. org/10.1111/jbi. 13554

Dudin, V. A. 2000. History of Kostroma forests. Kostroma. 256 pp. (In Russian).

Ekman, S. 1994. Biatora meiocarpa (Nyl.) Arnold, a misunderstood species. Lichenologist 26: 31-37. https://doi.org/10.1006/lich.1994.1002

Elenkin, A. A. 1906. The Lichen flora of Central Russia. Part 1. Yur'yev. 184 pp. (In Russian).

Elenkin, A. A. 1907. The Lichen flora of Central Russia. Part 2. Yur'yev. 360 pp. (In Russian).
Elenkin, A. A. 1911. The Lichen flora of Central Russia. Part 3-4. Yur'yev. 683 pp. (In Russian).

Fryday, A. M., Printzen, C. \& Ekman, S. 2014. Bryobilimbia, a new generic name for Lecidea hypnorum and closely related species. Lichenologist 46: 25-37. https://doi.org/10.1017/ S0024282913000625

Hafellner, J., Petutschnig, W., Taurer-Zeiner, C. \& Mayrhofer, H. 2005. Über einige bemerkenswerte Flechtenfunde in Kärnten, hauptsächlich in den Gurktaler Alpen. Carinthia II, 195: 423-440.

Hansen, E. S. \& McCune, B. 2010. The lichen genus Hypogymnia in Greenland. Folia Cryptogamica Estonica 47: 13-20.

Harris, R. C. \& Lendemer, J. C. 2010. A review of Lecania croatica (syn. Catillaria croatica) in North America. Opuscula Philolichenum 8: 41-49.

Harris, R. C., Brodo, I. M. \& Tønsberg, T. 2000. Lecanora thysanophora, a common leprose lichen in North America. Bryologist 103: 790-793. https:/ / www.jstor.org/stable/3244346

Himelbrant, D. E., Leostrin, A. V. \& Efimova, A. A. 2018. New records of lichens and lichenicolous fungi for the Kostroma Region. Novitates Systematicae Plantarum Non Vascularium 52(2): 246-448.

Himelbrant, D. E., Motiejūnaitè, J., Pykälä, J., Schiefelbein, U. \& Stepanchikova, I. S. 2013: New records of lichens and allied fungi from the Leningrad region, Russia. IV. Folia Cryptogamica Estonica 50: 23-31. https:/ / doi.org/ 10.12697 / fce.2013.50.04

Himelbrant, D. E., Stepanchikova, I. S., Kuznetsova, E. S., Motiejūnaite, J. \& Konoreva, L. A. 2018. Konevets Island (Leningrad Region, Russia) - a historical refuge of lichen diversity in Lake Ladoga. Folia Cryptogamica Estonica 55: 51-78. https://doi. org/ 10.12697 / fce.2018.55.07

Jørgensen, P. M. \& Nash, T. H. 2004. Leptogium. In: Nash III, T. H., Ryan, B. D., Gries, C. \& Bungartz, F. (eds.). Lichen Flora of the Greater Sonoran Desert Region, vol. I. Tempe, Arizona, Lichens Unlimited, Arizona State University. Pp. 330-350.

Kopaczevskaja, E. G., Makarevicz, M. F. \& Oxner, A. N. 1977. Handbook of the lichens of the USSR. 4. Verrucariaceae - Pilocarpaceae. Leningrad. 344 pp. (In Russian).

Korolev, Yu. B. \& Tolpysheva, T. Yu. 1980. Outline of the lichen flora of the field station "Contact" (The Upper Kolyma Upland). Novitates Systematicae Plantarum Non Vascularium 17: 137-149. (In Russian).

Kukwa, M. 2005. Lecanora thysanophora (Lecanoraceae, zlichenizowane Ascomycota) w Polsce. (In Polish, English summary). Fragmenta Floristica et Geobotanica Polonica 13: 385-391.

Kukwa, M., Łubek, A., Szymczyk, R. \& Zalewska, A. 2012. Seven lichen species new to Poland. Mycotaxon 120: 105-118. https://doi. org/ 10.5248/120.105

Kuznetsova, E. S. \& Skazina, M. A. 2010. Contribution to the lichen study to the Kostroma Region. No- 
vitates Systematicae Plantarum Non Vascularium 44: 200-209. (In Russian).

Ladyzhenskaya, K. 1931. Ecologycal list of lichens of the surroundings of the Kologriv city. Zhurnal Russkogo Botanicheskogo Obshestva 16(5-6): 544-553. (In Russian).

McCune, B., Tønsberg, T. \& Ahti, T. 2007. Hypogymnia incurvoides new to Scandinavia and the Appalachian Mountains. Graphis Scripta 19: 10-12.

Muchnik, E. E. 2013a. Lichens of "Orlovskoye Polesie" National Park (Oryol region, Central Russia): An annotated checklist. Research Notes of the Orel State University. Natural Sciences 6(56): 125-132. (In Russian, English summary).

Muchnik, E. E. 2013b. The diversity of the lichen biota of the Voronezh Nature Reserve: additions, alterations and protected species monitoring results. Proceedings of the IV international ecological Congress: "Ecology and life safety of industrial and transport complexes", Vol. 2, Toliatti-Samara, September 18-22, 2013. Toliatti. Pp. 145-150. (In Russian).

Muchnik, E. E., Braslavskaya, T. Yu. \& Tikhonova, E. V. 2018a. Additions to lichen biota of Smolensk Lakeland National Park (Smolensk Region). Proceedings of Petrozavodsk State University 8(177): 43-47. (In Russian, English summary). https:// doi.org/10.15393/uchz.art.2018.249

Muchnik, E. E., Dobrish, A. A., Makarova, I. I. \& Titov, A. N. 2007. The preliminary list of lichens of the Yaroslavl Region (Russia). Novitates Systematicae Plantarum Non Vascularium 41: 200-209. (In Russian).

Muchnik, E. E., Kondakova, G. V., Konoreva, L. A. \& Paukov, A. G. 2018b. New and rare lichens of the Yaroslavl' Region (Russia). Herald of Tver State University. Series: Biology and Ecology 1: 171-182. (In Russian, English summary).

Muchnik, E. E., Konoreva, L. A., Chabanenko, S. I., Taran, A. A. \& Anishchenko, L. N. 2017. Biota of lichens in Bryansk forest nature reserve. Lesovedenie 5: 73-80. (In Russian, English summary).

Nordin, A., Moberg, R., Tønsberg, T., Vitikainen, O., Dalsätt, Å., Myrdal, M., Snitting, D. \& Ekman, S. 2011. Santesson's Checklist of Fennoscandian Lichen-forming and Lichenicolous Fungi. Ver. April 29, 2011. http://130.238.83.220/santesson/ home.php (10 February 2019).

Notov, A. A. \& Himelbrant, D. E. 2013. New and noteworthy lichen records from the Tver Region. Herald of Tver State University. Series: Biology and Ecology 30: 85-91. (In Russian, English summary).

Notov, A. A., Himelbrant, D. E. \& Stepanchikova, I. S. 2014. New materials to the lichen flora of Tver region. Herald of Tver State University. Series: Biology and Ecology 2: 136-144. (In Russian, English summary).

Notov, A. A., Himelbrant, D. E. \& Urbanavichus, G. P. 2011. The list of lichens and allied fungi of Tver Region. Tver. 124 pp. (In Russian).
Orange, A., James, P. W. \& White, F. J. 2001. Microchemical methods for the identification of lichens. London. $101 \mathrm{pp}$.

Oset, M. \& Kukwa, M. 2010. The lichen genus Pertusaria in Poland I. P. multipuncta and P. ophthalmiza. Acta Mycologica 45(2): 231-238. https:// doi.org/10.5586/am.2010.028

Otte, V. 2001. Flechten und Moose im Gebiet des Bolschoi Tchatsch (NW-Kaukasus) - eine erste Übersicht, ergänzt durch einige von D. Benkert bestimmte Pezizales. Feddes Repertorium 112(7-8): 565-582. https://doi.org/10.1002/ fedr.4921120712

Palice, Z., Printzen, Ch., Spribille, T., Svensson, M., Tønsberg, T., Urbanavichene, I., Yakovchenko, L. S. \& Ekman, S. 2013. Taxonomy of the genus Myrionora, with a second species from the Southern Hemisphere. Lichenologist 45: 159-167. https://doi.org/10.1017/S0024282912000692

Presnyakova, M. G. 2001. New species of lichens from Nizhniy Novgorod Region. Novitates Systematicae Plantarum Non Vascularium 35: 200-202. (In Russian).

Printzen, C. 2007. New records of Cheiromycina species, a genus of lichenized hyphomycetes, with C. reimeri sp. nov. and a revised key to the species. Nova Hedwigia 84: 261-267. http:/ / dx.doi. org/10.1127/0029-5035/2007/0084-0261

Printzen, C., Halda, J., Palice, Z. \& Tønsberg, T. 2002. New and interesting lichen records from oldgrowth forest stands in the German National Park Bayerischer Wald. Nova Hedvigia 74: 25-49. https:/ / doi.org/ 10.1127/0029-5035/2002/00740025

Printzen, C. \& Otte, V. 2005. Biatora longispora, new to Europe, and a revised key to European and Macaronesian Biatora species. Graphis Scripta 17(2): 56-61.

Printzen, C. \& Palice, Z. 1999. The distribution, ecology and conservational status of the lichen genus Biatora in Central Europe. Lichenologist 31: 319335. https://doi.org/10.1006/lich.1999.0203

Pystina, T. N. 2003. Lichens of the taiga forests of the European North-East (southern and middle taiga subzones). Ekaterinburg. 239 pp. (In Russian).

Rassadina, K. A. 1967. Species et formae Hypogymniae novae et curiosae. Novitates Systematicae Plantarum non Vascularium 4: 289-300. (In Russian).

Red Data Book of Kostroma Region. 2009. Kostroma. 387 pp. (In Russian).

Red Data Book of Russian Federation (Plants and Fungi). 2008. Moscow. 855 pp. (In Russian).

Sharapova, M. G. 2001. To the lichen flora of the Nizhny Novgorod Zavolzhye. Novitates Systematicae Plantarum Non Vascularium 34: 206-212. (In Russian).

Stepanchikova, I., Kukwa, M., Kuznetsova, E., Motiejūnaitė, J. \& Himelbrant, D. 2010. New records of lichens and allied fungi from the 
Leningrad Region, Russia. Folia Cryptogamica Estonica 47: 77-84.

Tagirdzhanova, G. M., Kataeva, O. A. \& Stepanchikova, I. S. 2014. New lichen records from the Novgorod Region, Russia. Folia Cryptogamica Estonica 51: 103-107. https://doi.org/10.12697/ fce.2014.51.11

Tibell, L. \& Beck, A. 2001. Morphological variation, photobiont association and ITS phylogeny of Chaenotheca phaeocephala and C. subroscida (Coniocybaceae, lichenized ascomycetes). Nordic Journal of Botany 21: 651-660. https://doi. org/10.1111/j.1756-1051.2001.tb00824.x

Tomin, M. P. 1956. Handbook of crustose lichens of the European part of the USSR (except Far North and Crimea). Minsk. 533 pp. (In Russian).

Urbanavichene, I. N. 2018. Species of the genus Bryoria (Parmeliaceae) from the North Caucasus. Botanicheskiy Zhurnal 103(9): 1109-1123. (In Russian, English summary). https://doi. org/10.7868/S000681361809003X

Urbanavichene, I., Palice, Z. \& Urbanavichus, G. 2018. New lichen records from the mountain forests of Southern Siberia. Turczaninowia 21(3): 81-88. https://doi.org/10.14258/turczaninowia.21.3.11

Urbanavichene, I. N. \& Urbanavichus, G. P. 2001. About the lichen flora of Kerzhinskii Reserve (Nizhniy Novgorod Region).). Novitates Systematicae Plantarum Non Vascularium 35: 208-217. (In Russian).

Urbanavichene, I. N. \& Urbanavichus, G. P. 2014. Contribution to the lichen flora of the Achipse River valley (SW Caucasus, Krasnodarsky Kray). Novitates Systematicae Plantarum Non Vascularium 48: 315-326. (In Russian, English summary).

Urbanavichene, I. N. \& Urbanavichus, G. P. 2015. Additions to lichen flora of Mordovskii Reserve,
Republic of Mordovia, and Middle Russia. Proceedings of Petrozavodsk State University 8(153): 75-79. (In Russian, English summary).

Urbanavichene, I. N., Urbanavichus, G. P., Mežaka, A. \& Palice, Z. 2013. New records of lichens and lichenicolous fungi from the Southern Ural Mountains, Russia. II. Folia Cryptogamica Estonica 50: 73-80. https: / / doi.org/10.12697/fce.2013.50.10

Urbanavichus, G. P. \& Urbanavichene, I. N. 2014. The first addition to the lichenflora of the Republic of Mordovia and Middle Russia. Bulletin of Moscow Society of Naturalists. Biological series 119(3): 78-81. (In Russian, English summary)

Urbanavichus, G. P. \& Urbanavichene, I. N. 2015. New findings of lichen species in Mordovia Republic. Botanicheskiy Zhurnal 100(12): 1321-1323. (In Russian, English summary).

Velmala, S., Myllys, L., Goward, T., Holien, H. \& Halonen, P. 2014. Taxonomy of Bryoria section Implexae (Parmeliaceae, Lecanoromycetes) in North America and Europe, based on chemical, morphological and molecular data. Annales Botanici Fennici 51: 345-371. https://doi.org/ 10.5735/085.051.0601

Zhdanov, I. S. \& Volosnova, L. F. 2008. Preliminary list of lichens of Oksky Biosphere Reserve (Ryazan Region). Novitates Systematicae Plantarum Non Vascularium 42: 178-188. (In Russian, English summary).

Zhurbenko, M. P. 2004. Lichenicolous and some interesting lichenized fungi from the Northern Ural, Komi Republic of Russia. Herzogia 17: 77-86.

Zhurbenko, M. P. 2017. Lichenicolous fungi of the Caucasus: new species, new records and a second synopsis. Opuscula Philolichenum 16: 267-311. 